\title{
Transformational Leadership at Muhammadiyah Primary Schoolson Emotional Intelligence: Forward Bass \&Avolio Theory.
}

\author{
Sentot Imam Wahjono ${ }^{1}$, A. Dzo’ulMilal ${ }^{2}$, Anna Marina ${ }^{3}$, Sumadji Harryono ${ }^{4}$ \\ ${ }^{1}$ (Department of Technopreneurship, UniversitiTeknikal Malaysia Melaka, Malaysia) \\ ${ }^{2}$ (Department of Education, State Institute for Islamic Studies, SunanAmpel, Indonesia) \\ ${ }^{3}$ (Department of Accounting, Muhammadiyah University of Surabaya, Indonesia) \\ ${ }^{4}$ (Department of Management, Merdeka University of Surabaya, Indonesia)
}

\begin{abstract}
The aim of this research are examines the influence of Authentic Transformational Leadership behavior on Emotional Intelligence with intervening variables: Value CongruenceandTrust of the teachers and employees at MuhammadiyahPrimary Schools forward Bass \&Avolio Theory. Quantitative approach used on this research. The samples in this study were 55 employees and 110 teachers. The finding indicate that Authentic Transformational Leadership behavior have significant direct effect on Emotional Intelligence. The significant influence was also shown by intervening variables: Value Congruence (positive), andTrust (negative). For further studies there is recommended to conduct similar studies in high school Muhammadiyah, considering there are differences in the curriculum and the emotional maturity of students and teachers.
\end{abstract}

Keywords: Authentic Transformational Leadership, Emotional Intelligence, Muhammadiyah Primary School, Trust, Value Congruence.

\section{Introduction}

As a big religious and social organization, Muhammadiyah decided education as one of its service to the society and nation. Based on this reason, it makes sense that Muhammadiyah has thousands of schools from kindergarten to university level. The schools are spread out across the nation, from the metropolitan city like Jakarta to villages in Indonesia. It can be said that there are Muhammadiyah schools in every district of Indonesia and especially in Java, Sumatra and some other places Muhammadiyah schools can be found in as far as sub-districts and small villages. Therefore, Muhammadiyah schools has given a significant contribution to the national education. The Muhammadiyah schools quality will significantly influence the development of education in Indonesia (Samani, 2011, [1]).

The role played by Muhammadiyah in education improvement is indispensable in the context of the development of intellectual life of the nation. This is indicated by the number of Muhammadiyah schools spread throughout Indonesia. Until 2005, the number of Muhammadiyah schools is 13.803 consisting of 9.281 elementary schools and their equivalents, 3.426 junior secondary schools and their equivalents, 929 higher secondary schools and their equivalents, and 167 universities (Suyanto, 2006: 5, [2]). Some of them have become superior schools and many of them are making hard endeavor and competing to develop into superior schools.

The competition to become superior schools is motivated by the shift of educational orientation among Muhammadiyah schools. Making educational efforts which used to be aimed at freeing people from ignorance has shifted to the intention of empowering them to improve the quality of their faith and welfare quality. The shift of orientation is supported by the passing of Act number 20 year 2003 in National Education System.

The superiority of schools does not refer to superior input, superior process, nor superior output, but it lies on the superior process which requires maximal compliance with anything related to the teaching and learning process (Yusuf, 2004: 4 [3]). Therefore, competent human resources are required to be able to realize superior teaching and learning process.

The vision of National Education is oriented to the existence of Competitive and Intelligent Indonesian People as the vision of 2025 (Sudibyo, 2006: 2 [4]). The term Competitive and Intelligent people refers to those who are intelligent Spiritually, Emotionally and Socially, Intellectually, and Kinesthetically. The Principals as the agents who are in charge of forming competitive and intelligent human resources are required to be able to practice spiritual, kinesthetic, social, intellectual, and emotional intelligence. 
The statements above imply the importance of highly qualified human resources in education who are capable of influencing teaching and learning process at schools in order to form competitive and intelligent people. Hence, the role of the Principals in managing human resources at schools is very significant. Is there any relationship between the success of leadership and morality or religion?

This study is intended to uncover the relationship between Authentic Transformational Leadership (ATL) and Emotional Intelligence (EI) with two intervening variables, namely Value Congruenceand Trust of the leaders at MuhammadiyahPrimary Schools.

Leadership at religion-based educational institutions, such as those in Muhammadiyah, is an interesting phenomenon to observe. The curricula prescribed for Muhammadiyah schools contain more Islamic religion lessons than those for state-owned schools. The lessons included in local content curriculum of Muhammadiyah schools are Aqidah (Faith), Arabic Language, Ibadah(Religious Service), Al-Qur'an and Its Interpretation, Morality and About Muhammadiyah. Those lessons contain a lot of moral values, especially Islamic values. In addition to that, moral values are also inculcated through general subjects (such as Science, Mathematics, Indonesian Language, English, Javanese, Citizenship and Social Science, etc.). Those religious values are the foundation of Emotional Intelligence (Agustian, 2005, [5]).

The role of Muhammadiyah Education is currently being tested. This is marked by the increasing enthusiasm of the public to send their children to religion-based schools. Thus, the perception of religion-based schools as being number two educational institutions has begun to be eliminated. In some cities, the students at Muhammadiyah schools outnumber those at public schools. (For example, Muhammadiyah Elementary School 4 has 7 parallel classes, Muhammadiyah Junior Secondary School 5 has 7 parallel classes, Muhammadiyah Senior Secondary School 2 has 10 parallel classes. The data are taken from the Section of Elementary and Secondary Education, Muhammadiyah Administration for SurabayaMunicipality, for 2005/2006 academic year).

This implies that the public trust to Muhammadiyah schools is relatively high. This is a challenge for Muhammadiyah schools to show their readiness and ability to respond to that public trust consistently. The emergence of religion-based schools has become a new trend in transitional society. The parents' main expectation in sending their children to religion schools is to fortify the children from deviational behaviors, such as drug abuse, free sex, and other abnormal behaviors.

The inculcation of moral values in religion schools is also to prepare the children to face more complex life problems. They are educated not only to improve their intellectuality but also to exercise their morality.

Various moral values in Al-Qur'an and Hadits (Prophet's Sayings and Tradition) are presented to the children as mental education. Moral values (Noble Characters) have become embryonic point of intelligence, which has now become the central interest of studies to reveal the key factor to a success of leaders, namely Emotional Intelligence (Agustian, 2005: 200). Goleman et al. (2002, [6]), furthermore, found out that emotional intelligence is a key success factor for a child in successful life.

Leaders in public organization, such as those at Muhammadiyah schools (in this case the principals), are now being tested to realize the objective of the organization. Students are educated not only to improve their intellectuality but also to be intelligent emotionally. Teachers and employees also play their roles in influencing and directing the children because they are in direct contact with the students. The emotional sensitivity and intelligence of teachers and employees are expected to induce to students' hearts. Hence, students are expected to imitate or duplicate them to form high standard of students' behavior. The emotional sensitivity and intelligence of teachers and employees result from the emotional intelligence of authentic transformational leadership through open loop of limbic system (Goleman et al. 2002, [6]).

Leaders play a very significant and strategic role in any organizations. According to Goleman et al. (2002: 9), leaders have maximal power to influence other people's emotion. When the people's emotion is directed towards enthusiasm, their performance will increase. When their emotion is dragged towards hatred and anxiety, on the other hand, their performance will decrease. It implies that when the leader stimulates positive emotion, he will be able to drag out the best side of all people (Boyatzis\&Saatcioglu, 2008, [7]).

Principals have a very strategic role to satisfy the expectation of parents' and society in general, including the achievement of the school objectives. One way to develop the organization is through leadership development. The effectiveness of the principal's leadership determines the success of the school. Therefore, it is important to study the effect of authentic transformational leadership on the emotional intelligence of the teachers and employees at Muhammadiyah schools in Surabaya. 


\section{Authentic Transformational Leadership (ATL), Value Congruence, Trust Implied in Emotional Intelligent (EI)}

The following analysis will focus on the Transformational Leadership model described by Bass and Avolio (1990, [8]) and adapted by Northouse (2004, [9]). These dimensions define the TL behaviors and are characterized as follows (Table 1; Table2)

Table 1Dimensions of Transformational Leaders (Bass \&Avolio, 1990)

\begin{tabular}{|l|l|}
\hline $\begin{array}{l}\text { Idealized Influence } \\
\text { (II) }\end{array}$ & $\begin{array}{l}\text { Making others feel good, making others proud, earning faithfrom the } \\
\text { subordinate }\end{array}$ \\
\hline $\begin{array}{l}\text { Inspirational } \\
\text { Motivation (IM) }\end{array}$ & $\begin{array}{l}\text { Leader communicates his/her goals, the manipulation of images, helping } \\
\text { others find meaning in their work }\end{array}$ \\
\hline $\begin{array}{l}\text { Intellectual } \\
\text { Stimulation (IS) }\end{array}$ & $\begin{array}{l}\text { Leader's ability to make others think about new ways to perform work, } \\
\text { new ways to look at work, ways to be creative in their own problem- } \\
\text { solving methods }\end{array}$ \\
\hline $\begin{array}{l}\text { Individual } \\
\text { Consideration (IC) }\end{array}$ & $\begin{array}{l}\text { Individuals develop themselves, leader feedback to subordinates, time } \\
\text { taken by the leader to bring workers into the team or group }\end{array}$ \\
\hline
\end{tabular}

Northouse $(2004,[9])$ noted that the strengths of the TL model are that it allows for various perspectives, it is intuitive, and it is process-based (Table 2). Another strength is that the process seems intuitive to the leader because of the focus on the member needs.

Table 2Strengths and Weaknesses of Transformational Leadership (Northouse, 2004)

\begin{tabular}{|c|c|}
\hline Strengths & Weaknesses \\
\hline Various-perspective & Validity not fully tested \\
\hline Intuitive & State or trait \\
\hline Process-based & Elitist \\
\hline Augmented other model & Very "I" and "me" based \\
\hline Members' needs & Different contexts \\
\hline Effective & More study needed \\
\hline
\end{tabular}

Idealized influence of the leaders refers to dreaming, being certain, and forming high standard of equalizing effort. Inspirational motivation will be taken by the followers to face the challenge in achieving the goal. Intellectual stimulation of transformational leadership helps the followers to respond to the assumption and to find more creative solution to the problems. Individualized consideration means to treat each subordinate individually, to escort, to monitor, and to create chances. Authentic transformational leadership is marked by high moral and ethical standards of each component above.

Bass (in Bass and Steidmeier, 1998, [10]) characterizes the leaders who implement "Authentic Transformational Leadership" as follows:Leaders are authentically transformational when they increase awareness of what is right, good, important, and beautiful, when they help to elevate followers' needs for achievement and self-actualization, when they foster in followers higher moral maturity, and when they move followers to go beyond their self-interests for the good of their group, organization or society.

The literatures concerning authentic transformational leadership are related to the literatures that have been existent long time ago about moral and virtuous characters, as shown by Socrates and Confucius. These moral teachings are the foundation of emotional intelligence (Agustian, 2005: 50). Siswanto (2005, [11]) found out that transformational leadership at Islamic schools of modern pesantren have high values in the above four components. Kezar (2004, [12]) and Hsu et. al. (2005, [13]) also uncovers similar findings at religious institutions in Taiwan. This goes in line with Bass' (1985, [14]) opinion that authentic transformational leadership is marked by high values of the above four components.

Emotional intelligence is broadly defined as the ability to monitor feelings and self emotion and other's emotion to distinguish one from the other, and use such information top direct others' thought and behavior (Salovey\& Mayer, 1990, [15]). This definition emphasizes on some but related differences. Emotional intelligence can be conceptualized as individual awareness of self emotion and ability to express such emotions, to individual perceptions and awareness of such emotions to be expressed to others, to manage self and others' emotions, and to use those emotions. Goleman (1998, [16]) cites that the balance and management of our emotion determine the level of our intelligence to act and the success of our life. Goleman (1995, [17]) suggests a broad model of emotional intelligence. He states that the majority of human abilities which are included in emotional intelligence are: frustration, tolerance, delayed happiness, motivation, full of spirit, perseverance, controlling heart behavior, managing heart feelings, empathy, adjustability, expectation, and optimism. There 
are seven components in the variable of emotional intelligence (Yong, 2003, [18]). Those seven components are measured by "The Yong EQ Inventory", that is a self-report questionnaire consisting of 28 items measuring the 7 dimensions of emotional intelligence. Those seven dimensions are selected based on the literary study of the concept of EQ Inventory, such as Bar-on and Parker (2000, [19]), Salovey\& Mayer (1990, [15]).

Those seven dimensions include: Intrapersonal skills, namely ability to recognize self emotion and to create accurate and realistic self model, and the ability to effectively realize the model in life. Interpersonal skills include ability to understand others, their motivation, how they work, and how to cooperate with them.

Assertive estimates individual ability to express wants, opinions, feelings, and conviction directly, honestly, and ordinarily. Contentment in life refers to working with individual contentment and happiness in life. Resilience indicates individual ability to recover from disappointment, learn from failure, progress continuously, and persistent in facing grief (bad lucks). Self-esteem shows the feeling of pride, self-confidence, and self-respect.Someone with high self-esteem will think high of himself. Self-actualization measures individual potential achievement, a level where an individual believes that he has realized his potentials.

This study tests 5 hypotheses of the effect of Authentic Transformational Leadership(ATL) on Emotional Intelligence (EI) with intervening variables: Value Congruenceand Trust. Those two variables are regarded intervening variables based on Meglino et al. (1989, [20]), Kirkpatrick and Locke (1996, [21]), Podsakoff et al. (1990, [22]), and Bass'(1985, [14]) original model. Shamir et. al. (1993, [23]) states that trust and value congruence have positive role on leadership process. Max Weber, on the other hand, claims the importance of reverence in leadership process especially in charismatic/authentic transformational leadership.

\subsection{The Effect of ATL on Value}

Value is a basic beliefthat a certain behavioral mode or the end-state of a specific existence is individually or socially more preferable than another behavioral mode or an end-state (Robbins, 2005, [24]). Value contains an element of balance in the sense that it carries individual ideas about what is true, good, or wanted.

Value has attributes of content and intensity. Content attribute refers to the importance of behavioral mode or an end-state of existence. Intensity attribute specifies the level of its importance. If we rank individual values according to their intensity, we will know the values of the person.

Value generally influences attitude and behavior. The topics of values shared by workers and supervisors in a certain organizational culture have been carried out by some researchers. It is said that there is a positive relationship between the level of value congruence and performance of some levels in organization.Avolio and Gardner (2005, [25]) state transformational leadership is appropriate to form congruent values among members of organization.

Subordinates will voluntarily adjust themselves to the values practiced by their leaders because the leaders are willing to understand and try to get close with the subordinates. Barling and Kelloway $(2000,[26])$, on the other hand, state that the value congruence between subordinates and leaders can be intermediary between ATL and EI if there is no effect of ATL on EI or if the effect is negative. Barling and Kelloway (2000, [26]) say that the intermediating ability of value congruence is due to the fact that ATL has significant effect on value congruence of the subordinates.

\subsection{The Effect of ATL on Trust}

The trust to the leaders means positive expectation that a leader will not behave opportunistically (Robbins, 2005, [24]). Trust is historical-dependenceprocess based on relevant but limited samples of experiences. The term opportunistically refers to inherent risk and susceptibility in every trust relationship. Trust covers things that make someone susceptible, such as that when we reveal intimate relationship or dependent on other promises. Because of this attribute, trust gives a chance to disappointment or brings benefits. However, trust does not contain risk from oneself, but it entails willingness to take a risk. Subordinates' trust to the leader is one important variable which may become intervening variable of the effectiveness of transformational leadership (Podsakoff et. al. 1990, [22]; Yukl, 2010, [26]). The level of subordinates' trust to the transformational leader enables him and his followers to perpetually make efforts and face challenges.

Bass \&Avolio (1990, [8]) state that the leader who has transformational leader characteristics, such as showing appreciation to subordinates, being able to understand them, to estimate their ability, to give example of how to lead life, to recover from disappointment, to learn from failure, to undergo perpetual progress, to be persistent in facing grieves (misfortunes), and to arouse reverence of the subordinates.

\subsection{The Effect of ATL on EI}

Barling, Slater, and Kelloway (2000, [26]) find out that the leader who has high emotional intelligence will prefer to choose transformational leadership style. Yong (2003) states "managers and leaders, need to have high emotional intelligence because they represent organization to the public, interact with many people inside 
and outside the organization, and create employees' morality”. According to Goleman (2002, [27]) emotional intelligence is a requirement for successful leaders, because:

First, the leader knows and can manage hisown emotion. The leader controls himself, delays satisfaction, and becomes a model for his followers. Thus, it increases trust and reverence (idealized influence).

Second, emphasizing on understanding others' emotion, the leaders with high emotional intelligence will be able to increase the expectation of the followers, a sign of inspirational motivation. Third, the main component of individualized consideration is the ability to recognize the followers' needs and interact with them harmoniously. Emphasizing of the empathy and ability to manage positive relationship, the leaders with high emotional intelligence will show individualized consideration.

Other researchers who relate emotional intelligence and leadership, among others, are: Bass (1985, [14]), Barlinget. al. (2000, [26]), and Krisnan (2005, [28]).Goleman (1995, [17]) claims that emotional intelligence is a key success factor for a leader as well as for an individual in life. According to Goleman, Boyatzis, and McKee (2002, [7]) great leader arouses spirit andinspires his followers through their work by involving emotion. Agustian (2001, [5]) in his preface says that his experience in implementing transformational leadership style improves the emotional intelligence of his followers. They feel brightened after Morning Briefing given for about 30 minutes to start the working days. The materials in the Morning Briefing are not technical matters about what and how to work to increase their performance but they are dealing with commitment, integrity, open mind, vision, the meaning of hard work, endurance, and creativity. Although the materials are not technical works to improve performance, the result is the improvement of performance. This implies that transformational leadership influences the improvement of emotional intelligence and finally increases performance.

\subsection{The Effect of Value Congruence on EI}

Bass (in Bass and Steidmeier, 1998, [10]) claims that the congruence of values between the leader and the subordinates concerning truth-falsehood, goodness-badness, and beauty increases the emotional intelligence of the subordinates indicated by a higher level of moral maturity. Value congruence can be mediate the relationship between Transformational Leadership and Emotional Intelligence (Siswanto, 2005, [11]; Kirkpatrick and Locke, 1996, [21]). Allen et. al. (2005, [29]) suggests that the value congruence between the followers and organizational culture has positive relationship with the level of commitment of the followers.

Meglinoet. al. (1989, [20]) explains positive influence of value congruence and individual outcome. They suggest that individuals with congruent values attempt to distribute various certain aspects and the congruence will help smoothen communication. When the values of the followers is congruent with that of the transformational leaders, they are expected to change their motivation from focusing on individual benefit to collective benefit.

\subsection{The Effect of Trust on EI}

Kirkpatrick and Locke (1996, [21]) state that transformational leaders can exert the trust of the followers to improve their emotional intelligence by taking care of subordinates' needs, fulfilling promises, showing competence and perseverance to achieve the vision, and willing to sacrifice for the sake of organization and group.Avolio and Gardner (2005, [25]) present an idea, to improve the trust of the followers is done by frequently empowering and giving spirit to the subordinates to make decision by themselves.Being a role model and showing appreciation to the subordinates, transformational leaders will be more reverenced, respected, and trusted along the time (Bass \&Avolio, 1990, [8]).

\section{Method}

There are three kinds of variables in this study: independent variable, intervening variables, and dependent variable. The independent variable is Authentic Transformational Leadership (ATL). The intervening variables intermediating between ATL and Emotional Intelligence (EI) are: Value Congruence andTrustof the leaders. The dependent variable is Emotional Intelligence (EI) of the subordinates.

The data were primary data collected by the researchers using questionnaires distributed to the respondents. The population was teachers and employees of MuhammadiyahPrimary Schools in Surabaya. Their number is 459 persons consisting of foundation-owned teachers/employees, hired teachers, and state-owned teachers. Purposive random sampling was used, that is a sampling technique by taking special consideration.

The samples were teachers and employees at MuhammadiyahPrimary Schools under the management of the Muhammadiyah Administration of Surabaya, consisting of 6PrimarySchools of Muhammadiyah: SDM (SekolahDasarMuhammadiyah) 4 Pucang, SDM 6 Gadung, SDM 12 Dupak Jaya, SDM 15 KedurusWiyung, SDM 16 Barata Jaya, SDM 26 Keputih. 
The number of samples was determined using a sampling table developed by Krejcie and Morgan. With 5\% degree of freedom and 459populations of teachers and employees, the number of sample taken was 210 persons.

Based on the research problems and hypotheses, the variables were classified as follows:

1. Independent Variable:

Authentic Transformational Leadership (X1) is broken down into four components:

Idealized Influence, Inspirational Motivation, Intellectual Stimulation, and Individualized Consideration.

2. Dependent Variable:

The dependent variable in this study is:

$\mathrm{Y}=$ Emotional Intelligence

3. Intervening Variables:

The variables intermediating between independent and dependent variables consist of:

$\mathrm{X} 2=$ Value Congruence

$\mathrm{X} 3=$ Trust

To measure ATL, a Multifactor Leadership Questionnaire (MLQ) developed by Bass \&Avolio (1990, [8]) was used. To measure the intervening variables (Value Congruence, Trust, and Reverence), moreover, a measuring instrument was developed by the researchers, and so was that to measure EI. Therefore, the validity and reliability of each of the instruments were tested. The items were in the forms of cross checks and responses to each of the questions measured using Likert Scale: number $1=$ very disagreeable, $2=$ disagreeable, $3=$ indeterminate, $4=$ agreeable, and $5=$ very agreeable. The data were analyzed using SPSS (Statistical Product and Service Solution) for Windows Release 17.0.

To test the hypotheses, Path Analysis was used. That is intended to uncover direct and indirect effect of ATL variable on contention with the leaders and EI with intervening variables: value congruence between principals and teachers/employeesand trust to the leaders. To obtain consistent result of Path Analysis, checking assumption and implementing theory of trimming were done. To interpret the analysis results, calculating the total effect of each variable which has causal effect on endogen variable (Tolmie, Daniel \& Erica,2011, [30]) was conducted.

\section{Finding And Discussion}

To test the validity of items, the questionnaires were distributed to 30 respondents. The result of testing validity on ATL variable indicated that 10 items were not valid, namely Q52, Q57, Q70, Q73, Q75, Q77, Q79, Q80, Q84, and Q 86. The other 27 items were valid. The above 10 non-valid items were revised. There were 6 items which were valid with 5\% degree of significance, namely Q56, Q64, Q65, Q67, Q69 and Q71. The other 21 items were valid with $1 \%$ degree of significance.

The result of testing validity of instrument to measure Trust of teachers and employees indicated that all items were valid with $1 \%$ degree of significance. And, so are those to measure Value Congruence and Reverence of teachers and employees. The instrument to measure EI contained 19 items. The test of validity showed that 3 items were not valid, thus revised, i.e. Q37, Q39, and Q43. Four items were valid with 5\% degree of significance, i.e. Q32, Q35, Q 36, and Q40. The rest were valid with 1\% degree of significance.

The reliability test indicated that the instruments were reliable. The reliability of instrument to measure ATL variable was high, shown in table 3.

Table 3 The Results of Reliability Test of Research Variables

\begin{tabular}{|l|c|c|c|}
\hline & Variables & $\begin{array}{c}\text { Alpha } \\
\text { Coefficient }\end{array}$ & Decision \\
\hline $\begin{array}{l}\text { Independent } \\
\text { Variable }\end{array}$ & ATL & 0.9211 & Good reliability \\
\hline $\begin{array}{l}\text { Intervening } \\
\text { Variables }\end{array}$ & $\begin{array}{c}\text { Trust of Subordinates to } \\
\text { Leaders }\end{array}$ & 0.7417 & $\begin{array}{c}\text { Acceptable } \\
\text { reliability }\end{array}$ \\
\cline { 2 - 4 } & $\begin{array}{c}\text { Value Congruence between } \\
\text { Leaders and Subordinates }\end{array}$ & 0.8298 & Good reliability \\
\hline Dependent Variable & EI & 0.8630 & Good reliability \\
\hline
\end{tabular}

Source: Data analyzed in enclosed tests of reliability and validity.

\subsection{Interpretation the Finding}

Hypothesis 1 stating that ATL affects Value Congruence of teachers and employees is accepted. Fig. 1 shows the effect of ATL on Value congruence is $0.717(\mathrm{t}$-test $=13.753 / \mathrm{sig}$. $=0.000)$. This is consistent with 
Avolio and Gardner's (2005, [25]) idea that transformational leaders are suitable to form value congruence of the members of organization. Subordinates try to voluntarily adjust themselves to the values practiced by the leaders because the leaders are willing to understand and to be close to them. Barling\&Kelloway (2000, [26]), on the other hand, say that ATL has significant effect on subordinates' values congruence.

Hypothesis 2 stating that ATL affects Trust of the teachers and employees to the Principal is accepted. Fig. 1 describes that the effect of ATL on Trust is $0.548(\mathrm{~T}$-test $=7.228 / \mathrm{sig} .=0.000)$. This goes in line with Podsakoff'et. al. (1990, [22]) view, there is a strong influence of transformational on trust. Subordinates will trust the leaders who comply with transformational leaders' characteristics, such as escorting when they get problems, inspiring, and helping them find creative solution. Yukl (2002, [26]) also finds that transformational leadership affects the trust of subordinates to the leaders.

Hypothesis 3 saying that ATL affects EI of teachers and employees directly is accepted. The three independent variables simultaneously affect EI with the score 0.587 because F-test $=65.983 /$ sig. $=0.000$ $(\mathrm{p}<5 \%)$. Partially, ATL affects EI with the score 0.578 is valid because $t$-test $=6.451(\mathrm{p}=0,000 / \mathrm{p}<5 \%)$. This is consistent with Barling's idea. Barling\&Kelloway (2000, [26]) also Bass and Steidmeier (1998, [10]) found out that the leaders with high EI prefer to choose transformational leadership style. Yong (2003, [18]) states that managers and leaders, specially need to have high EI because they represent organization to the public, they interact with many people inside and outside the organization, and they form employees' morality. This result, however, does notagree with Siswanto's (2005, [11]) finding that there is no direct effect of ATL on EI. Goleman (1998, [16]) says that EI is a pre-requisite for successful leaders, meaning that if ATL does not have direct effect on EI, intermediating variables which have positive effect on EI should be uncovered.

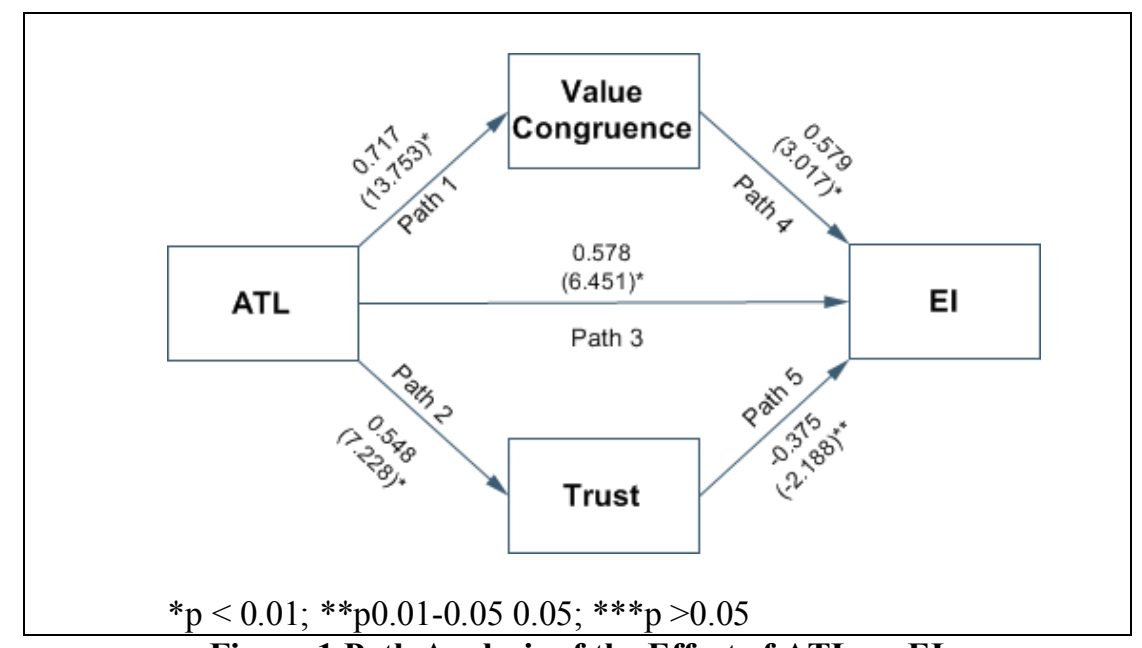

Figure 1 Path Analysis of the Effect of ATL on EI

Hypothesis 4 claiming that Value Congruence affects EI of teachers and employees is accepted. The score of 0.579 is valid, because t-test $=3.017(\mathrm{p}=0.000 / \mathrm{p}<5 \%)$. This agrees with Meglino'set. al. $(1989,[20])$ opinion stating that there is a positive effect of value congruence on individual outcome. Allen et. al (2005, [29]) also say that value congruence between followers and organizational culture has positive relationship with the commitment level of the followers.

Hypothesis 5 saying that Trust to leaders influences EI of teachers and employees is rejected. The score of -0.375 is valid, because $t$-test $=-2.188$ with significance of $0.054(p>5 \%)$. This is different from Kirkpatrick \& Locke (1996, [21]) who found out that there is a positive effect of trust on EI. This result also diverges from Avolio\& Gardner (2005, [25]) who claim that to improve trust of the followers is done by frequently empowering and giving spirit to the subordinates to make decision by themselves and to increase their EI.Those results can be figured as figure 1 above.

\subsection{Discussion}

The results of this study reveal that among the seven tested hypotheses, five show significant effect, namely $\mathrm{H} 1, \mathrm{H} 2, \mathrm{H} 3$, and $\mathrm{H} 4$ with high degree of significance (below 1\%). The other one (H5), however, having slightly lower degree of significance (above 5\%). The results also show that the five hypotheses (H1, H2, H3, and H4) are accepted because they have significant effect, whereas the other one (H5) are rejected, because they have negative effect. The scores of negative effect make the hypotheses rejected which require greater positive effect.

This implies that ATL has direct effect on EI. This is consistent with Meglinoet al (1989, [20]), Kirkpatrick and Locke (1996, [21]), Podsakoffet. al. (1990, [22]), Bass' (1985, [14]) original model, and Shamir 
et. al (1993, [23]). But, it does not agree with Siswanto (2005, [11]) who states that ATL does not have direct influence on EI of teachers and employees at Madrasah Aliyah (Islamic High Schools) in Jombang, thus it needs to be mediated by intervening variables.

One of the causes of difference is that the recruitment of Principals in Muhammadiyah schools under study was more democratic, more transparent, and involved more teachers and employees than that in Madrasah AliyahJombang. In addition to that, the foundation (in this case The Elementary \& Secondary Education Section) decides and inaugurates only the principals who get the highest scores (and the most votes). The recruitment process starts from teachers and employees' submission of candidates. Then, they are tested based administrative requirements determined by The Elementary \& Secondary Education Section.Only those who comply with the administrative requirements are apt to follow the following process, i.e. fit and proper test. The result of fit and proper test determines (usually) 3 candidates to be voted by the teachers and employees.

The study also reveals that the effect of ATL on EI is mediated by intervening variables: Value Congruence and Trust to the leaders. Trust to the leaders variables, however, have negative score in influencing EI of teachers and employees. This negative effect indicates that the leaders' behavior to seek trust of the subordinates turns out to affect negatively on EI. Subordinates' perception of the leaders' pursuit of trust is negative because it is regarded as a sign of the leaders' lack of self confidence and incapable of showing individual performance. Hence, teachers and employees consider their principals have been naïve; and this, consequently, degrades the EI of teachers and employees.

The teachers and employees also see that the principal's efforts to arouse teachers and employees' reverence to him, either it is done by himself or through the organization system even degrades their respect and stimulates their prejudice. Thus, the EI decreases. The teachers and employees prefer that the principal's achievements are not showed off. That is because showing off achievements indicatesarrogance, asking for rewards, and insincerity of the principal. This, consequently, decreases the EI of teachers and employees.

The negative effect brought by intermediating variables of Trust to the leaders of teachers and employees to the principal in this study does not agree with Podsakoffet. al. (1990, [22]) and Yukl (2010, [26]). The negativeness of Trust to the leaders may be caused by homogeneity of teachers, employees, and principal. All of them start from the same ideology, i.e. Muhammadiyah, thus they think they do not need to build a specific trust of the leaders. The teachers and employees are convinced that the principals working in Muhammadiyah schools have undergone undoubtedly strict selection system conducted by The Primary Education Section. Also may caused by the egalitarian condition at the schools under study while setupplanning (e.g. a school budgeting), organizing, implementing, and evaluating all school programs are conducted collectively in accordance with each own role and function. So, the activities and personalities of teachers and employees are proportionately functional. They all have equal degree, right, and obligation.

\section{Conclusion}

The advantage of this research is discovery of a direct relationship between ATL with EI it strengthens the findings of Bass and Steidmeierand just trust that could be intervening.The limitation of this study lies on its instrumentation. The instruments used were standard instruments, thus opening the possibility of errors in translation. That affects the perception of teachers and employees. Besides, the analyses of primary schools were combined despite their different characteristics which might bring about the possibility of different results.

Moreover, all objects of the study were high schools in Surabaya, thus requiring special judgment for generalization. Possibility to apply for next research is for high school in Muhammadiyah or other religiousbased schools.

\section{Journal Papers:}

\section{Reference}

[1]. Boyatzis, R. E. \&Saatcioglu, A. (2008). A twenty-year view of trying to develop emotional, social and cognitive intelligence competencies in graduate management education. Journal of Management Development, 27(1), 92-108.

[2]. Bass, Bernard M., and Paul Steidmeier. 1998. Ethics, Character, and Authentic Transformational Leadership (electronic version), Leadership Quarterly, 10(2), 181-218. Available from http://cls.binghamton.edu/BassSteid. html.

[3]. Kezar, Adrianna. 2004. Philosophy, Leadership, Scholarship: Confucian Contributions to a Leadership Debate, Leadership Review, Vol. 4, Fall pp. 110-131.

[4]. Meglino, B.M, Ravlin E.C., and Adkins C.L. 1989. A work values approach to corporate culture: A field test of the value congruence process and its relationship to individual outcomes, Journal of Applied Psychology, Vol. 22 No. 1 pp. $424-432$.

[5]. Kirkpatrick, S.A. and Locke, E.A. 1996. Direct and Indirect Effect of three core charismatic leadership component on performance and attitudes, Journal of Applied Psychology, Vol. 81 No.1 pp. 36-51.

[6]. Podsakoff, P.M., Niehoff, B.P., Moorman, R.H. \& Fetter, R. 1990. Transformational leader behaviors and their effects on followers' trust in leader, satisfaction, and organizational citizen behaviors. Leadership Quarterly, 1, 107-142.

[7]. Shamir, B., House, R.J. \& Arthur, M.B. 1993. The motivational effects charismatic leaders: A self-concept based theory. Organizational Science, 4, 577-594. 
[8]. Barling, J., Slater F \& Kelloway E.K. 2000. Transformational Leadership and Emotional Intelligent: An Exploratory Study, Leadership \& Organizational Development Journal, Vol.21 No.3, pp 157-161.

[9]. Krisnan, Venkat R. 2005. Leader-Member Exchange, Transformational Leadership, and Value System, Electronic Journal of Business Ethics and Organization Studies 10 (1): 14-21.

\section{Books:}

[10]. Agustian, Ary Ginanjar. 2005. ESQ, The Secret Recipe to Build Emotional and Spiritual Intelligent Base on 6 Point of Faith and 5 Point of Islam, Arga Publisher, Bandung.

[11]. Goleman, D. Annie McKee, Richard E..Boyatzis.. 2002. Primal Leadership: Realizing the Power of Emotional Intelligence. Boston: Harvard Business School Press.

[12]. Bass, Bernard M., and Bruce J Avolio. 1990. Manual for the Multi-factor Leadership Questionnaire, Palo Alto, CA: Consulting Psychologist Press.

[13]. Northouse, P. G. 2004. Leadership: Theory and practice. Thousand Oaks: Sage.

[14]. Hsu, Wei-Ling, Bor-Shiuan Cheng, Min-Ping Huang, and Jiing-Li Farh. 2005. Moral Leadership in Taiwanese Organizations: Developing the Construct and the Measurement, Department of Psychology National Taiwan University. Available from d88227001@ms88.ntu.edu.tw.....24pp

[15]. Bass, Bernard M. 1985. Leadership \& Performance Beyond Expectations, New York: Free Press.

[16]. Salovey, P. Mayer, JD. 1990. Emotional Intelligence: Imagination, Cognition, and Personality, 9, $185-221$

[17]. Goleman. 1998. Working with Emotional Intelligence, New York: Bantam.

[18]. Goleman. 1995. Emotional Intelligence, London: Bloomsbury.

[19]. Bar-On, R., Parker J.D.A.(Eds.) 2000. The Handbook of Emotional Intelligence: Theory, Development, Assesment, and Application at home, school and in the workplace, San Fransisco: Jossey-Bass.

[20]. Robbins, Stephen P. 2005. Organizational Behavior.Eleventh Edition. Pearson, Prentice Hall, Inc. New York.

[21]. Avolio, Bruce J. and William L Gardner. 2005. Authentic Leadership Development: Getting to the root of positive forms of leadership, Gallup Leadership Institute, Nebraska.

[22]. Yukl, Gary. 2010. Leadership in Organizations, Upper Saddle River, New Jersey: Pearson Education.

[23]. Goleman, D. Annie McKee, Richard E..Boyatzis.. 2002. Primal Leadership: Realizing the Power of Emotional Intelligence. Boston: Harvard Business School Press

[24]. Allen, Malcolm and Elizabeth Harrison. 2005. Enabling and Empowering Authentic Transformational Leaders, Authentic Transformational Leadership Institute, New York.

[25]. Tolmie, Andy, Daniel Muijs, Erica McAteer. 2011. Quantitative Methods in Educational and Social Research using SPSS, Open University Press: McGraw-Hill Education.

\section{Theses:}

[26]. Siswanto. 2005. The Effect of Authentical Transformational Leadership to Teacher and Employee Satisfaction at Madarasah Aliyah in Jombang, Universitas Airlangga Disertation, Surabaya.

\section{Proceedings Papers:}

[27]. Samani, Muchlas. 2011. Rebranding For Muhammadiyah Schools.Paper presented at the National Olympiad Conference with a theme Building International Collaboration in Education to Face Globalization. Malang May 14.

[28]. Suyanto. 2006. Muhammadiyah Education in term of National Education. Paper presented at the National Workshop of Muhammadiyah Elementary and Secondary Education Council. Juni, Jakarta.

[29]. Yusuf, M.Yunan. 2004. Formulation of Strength and Opportunity of Muhammadiyah Education. Paper presented at the National Workshop of Muhammadiyah Elementary and Secondary Education Council. Juni, Jakarta.

[30]. Sudibyo, Bambang. 2006. Strategic Planning of National Education Ministry of Indonesia. Paper of National Education Minister presented at the National Workshop of Muhammadiyah Elementary and Secondary Education Council. Juni, Jakarta.

[31]. Yong, Leonard. 2003. Yong EQ Inventory: Norm \& Technical Manual, Kuala Lumpur: LPI Sdn Bhd. www.leonard.com.my. 